\author{
MARIUSZ LEŃCZUK \\ Instytut Języka Polskiego Polskiej Akademii Nauk \\ ORCID: 0000-0003-0731-4056 \\ e-mail: mariusz.lenczuk@gmail.com \\ WIESŁAW WYDRA \\ Uniwersytet im. Adama Mickiewicza w Poznaniu \\ ORCID: 0000-0002-8126-677X \\ e-mail: wydra@amu.edu.pl
}

\title{
FRAGMENT KALENDARZA W JĘZYKU POLSKIM Z XIV/XV WIEKU ZE ZBIORÓW BIBLIOTEKI JAGIELLOŃSKIEJ W KRAKOWIE
}

W rękopisie Biblioteki Jagiellońskiej nr 1564 znajduje się dotychczas niewydany fragment kalendarza $\mathrm{w}$ języku polskim pochodzący $\mathrm{z}$ ostatnich lat XIV wieku lub pierwszych lat XV wieku. Kodeks powstał w 1404 roku, liczy 282 karty papierowe i zawiera następujące dzieła: 1. Matthias de Legnica, Postilla super epistulas dominicales et quadragesimales, 2. Caesarius Arelatensis, Sermones ex integro a Caesario compositi vel ex aliis fontibus hausti. Sermo 54, 3. Matthias de Legnica, Postilla super epistulas dominicales et quadragesimales. Fragmenta sermonum 39, 40 in dom. 7 et 8 post Trinitatem, 4. Biblia Latina cum Prologis. Novum Testamentum. Fragm.: Mt-Io, 5. Biblia Latina cum Prologis. Vetus Testamentum. Fragm.: Sap, Eccli.

$\mathrm{Na}$ końcu manuskryptu znajdują się trzy dodatkowe karty. Dwie pierwsze zawierają następujące teksty: k. Iv-r Iacobus de Voragine, Sermones de tempore. Fragm. 2 oraz k. IIr Bernardus Claraevallensis OCist., Sermo 2 in dom. Palmarum: De passione, et processione, et quattuor ordinibus processionis. Fragm. ${ }^{1}$. Trzecia to interesująca nas karta pergaminowa (k. III), która mieści wspomniany fragment kalendarza. W katalogu średniowiecznych rękopisów Biblioteki Jagiellońskiej został on opisany następująco:

f. IIIv: Kalendarium liturgicum ritus Palaeoslavici (Benedictinorum?). Fragm. Ianuarii et Februarii Janvary gyma dny trydzesczy ygeden nocz gyma godzyn szestnaczcze a dzen osm. la janvary

${ }^{1}$ Dokładny opis tego rękopisu - Katalog: 344-348. Opis rękopisu nr 1564 sporządzili R. Tatarzyński i A. Sobańska. 
obrzazanye Yeszu ...> $>18$ g Swøtego Sylwa<na>|| XIV ex. (1390 seu 1396), Palaeopol., membr., olim integ. post. aggl., nunc deglutinatum, tabula posteriore aliquanto minus, detritum et paulo defectivum, originaliter folium maiorum dimensionum, dextra parte praecisum (opinio est Marii Leńczuk, Lexiconis linguae Palaeopolonicae cooperatoris)" (Katalog: 347).

Z kalendarza ocalało pierwszych 13 dni stycznia (od 1 do 13 stycznia) oraz 13 dni lutego (od 4 do 19 lutego). W poniższej transliteracji zabytku czcionką półgrubą oznaczono cyfry i litery pisane rubrum. Kalendy, nony i idy w rękopisie oddawane są czerwonym atramentem w postaci wielkich liter, oznaczających określone dni w kalendarzu (co było wtedy powszechne ${ }^{2}$ ) - ze względów technicznych powtarzamy je jednak przy poszczególnych dniach, oznaczając literami: K, N, Id.

\begin{tabular}{|c|c|}
\hline \multicolumn{2}{|c|}{ Transliteracja } \\
\hline$<$ Styczeń $>$ & $<$ Luty $>$ \\
\hline Janvary gyma dny try & 4 g Id. ${ }^{1}$ Swøtego Wedaft<.> \\
\hline dzefczy ygeden $\cdot$ nocz gyma & 5 a Id. ${ }^{1}$ \\
\hline godzyn szeftnaczcze $\cdot$ a dzen ofm & 6 b Id. \\
\hline 1 a janvary $\cdot$ obrzazanye yefzu & 7 c Id. Swøtey Apolony \\
\hline $2 \mathrm{~b} \mathrm{~N}$ & 8 d Id. Swøtego Emilya<..> \\
\hline $3 \mathrm{c} \mathrm{N}$ & 9 e Id. Swøtego Amona \\
\hline $4 \mathrm{~d} N$ & 10 f Id. Swøtey Sotery \\
\hline 5 e $\mathbf{N}$ vygylya fczodrego dnya & 11 g Id. Swøtey Ewfraf<..> \\
\hline 6 f Id.Sczodry dzen & 12 a K Swøtego Damy<a.. $>^{2}$ \\
\hline $7 \mathrm{~g}$ Id. & 13 b K Swøtego Jvlyan $<\mathrm{a}>3$ \\
\hline 8 a Id.Swøtego Lvcyana mø & 14 c K Swøtego Vytalif<.>4 \\
\hline 9 b Id.Swøtego Igynyego pap & 15 d K Swøtego Favfti<..> \\
\hline 10 c Id. & 16 e K Swøtego Felyks $<a>^{5}$ \\
\hline 11 d Id. Swøtego Sabnyego mø & $17 \mathrm{f} \mathrm{K}$ \\
\hline 12 e Id. Swøtego Archadyego m. & 18 g K Swøtego Sylwa<..> \\
\hline 13 f Id. Swøtego Ilaryego bylkv & 19 a $\mathrm{K}$ \\
\hline
\end{tabular}

${ }^{1}$ Tak $w$ rękopisie zamiast None. ${ }^{2}$ Tak $w$ rękopisie zamiast Idus; Damy<a.. $>-$ zachowat sie poczatkowy fragment ostatniej litery a. ${ }^{3}$ Tak $w$ rękopisie zamiast Idus; Jvlyan $<\mathrm{a}>-$ zachowat się początkowy fragment ostatniej litery a. ${ }^{4}$ Vytalif<.> $>$ zachowaty się górne fragmenty liter if. ${ }^{5}$ Felyks $<\mathrm{a}>-$ zachowat się poczatkowy fragment litery a.

\begin{tabular}{|c|c|}
\hline \multicolumn{2}{|c|}{ Transkrypcja } \\
\hline$<$ Styczeń> & $<$ Luty $>$ \\
\hline January jima dni trzy- & 4 g Id. Świętego Wedast $<a>$ \\
\hline dzieści jeden. Noc jima & 5 a Id. \\
\hline godzin szestnaćcie, a dzień ośm. & $6 \mathrm{~b}$ Id. \\
\hline 1 a January. Obrzazanie Jezu $<\mathrm{sa}>$ & 7 c Id. Świętej Apoloni<ji> \\
\hline $2 \mathrm{~b} \mathrm{~N}$ & 8 d Id. Świętego Emilija <na $>$ \\
\hline $3 \mathrm{c} \mathrm{N}$ & 9 e Id. Świętego Amona \\
\hline $4 \mathrm{~d} \mathrm{~N}$ & 10 f Id. Świętej Sotery \\
\hline 5 e N Wijilija Szczodrego dnia & 11 g Id. Świętej Eufraz<yji> \\
\hline 6 f Id. Szczodry dzień & 12 a K Świętego Damija <na $>$ \\
\hline $7 \mathrm{~g}$ Id. & 13 b K Świętego Julijana \\
\hline 8 a Id. Świętego Lucyjana mę<czennika> & 14 c K Świętego Witalis $<a>$ \\
\hline
\end{tabular}

${ }^{2}$ Por. np. fotografie kart z kalendarzy - Włodarski (red.) 1957: 77, 147, 177. 
9 b Id. Świętego Iginijego pap $<$ ieża $>$

$10 \mathrm{c} \mathrm{Id}$.

11 d Id. Świętego $S a b<i>$ nijego $m<$ ęczennika>

12 e Id. Świętego Arkadyjego m<ęczennika>

13 f Id. Świętego Ilaryjego bisku<pa>
15 d K Świętego Fausty<na>

16 e K Świętego Feliksa

$17 \mathrm{f} \mathrm{K}$

18 g K Świętego Sylwa<na>

19 a K

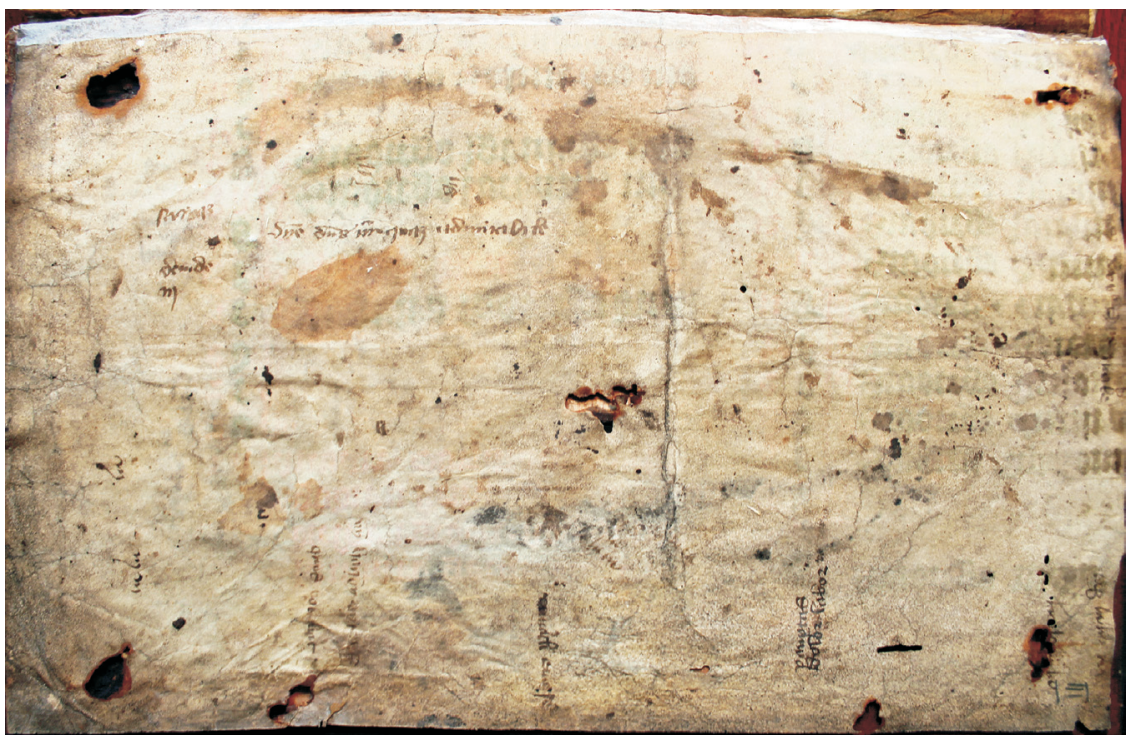

Ryc. 1. Rkps Biblioteki Jagiellońskiej nr 1564, k. IIIr.

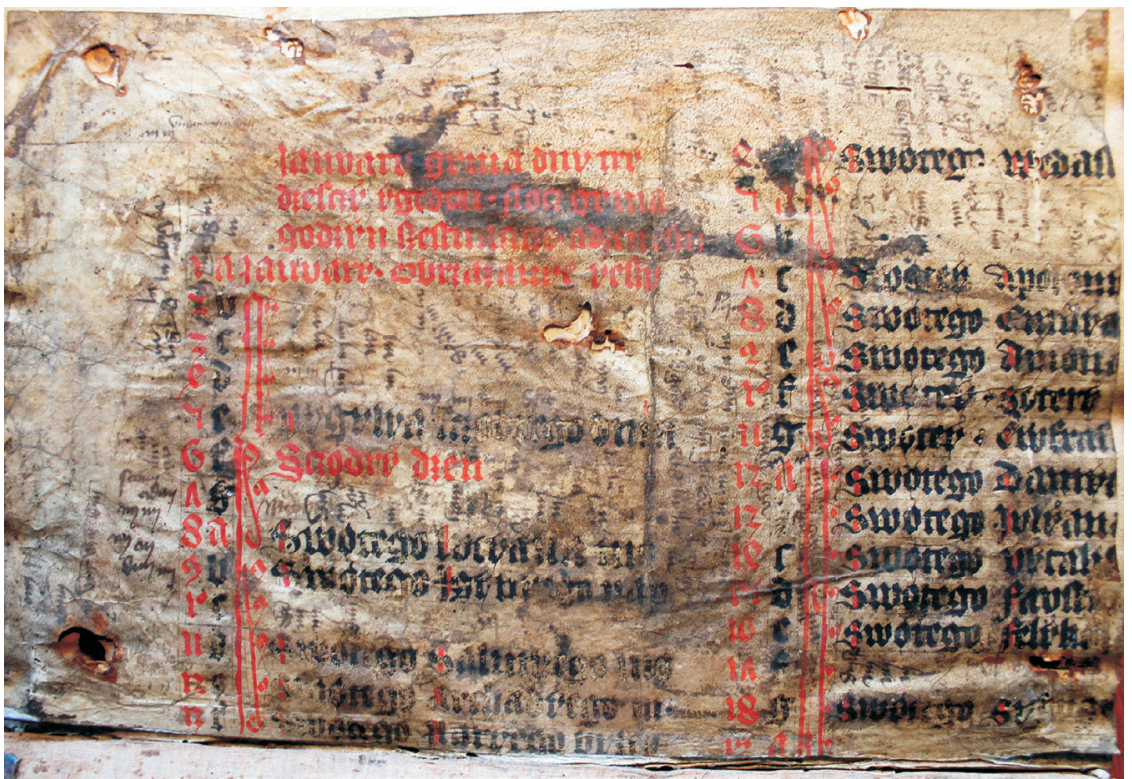

Ryc. 2. Rkps Biblioteki Jagiellońskiej nr 1564, k. IIIv. 
Przyjrzyjmy się, w których polskich kalendarzach średniowiecznych notowani są wymienieni wyżej święci³:

Styczeń:

6 f Szczodry dzień - Epiphania Domini.

8 a Świętego Lucyjana mę<czennika> - Luciani m., Włodarski: Włocławek (Luciani, Maximiani et Juliani m.); Wąsowicz nie notuje.

9 b Świętego Iginijego pap<ieża> - Igini (Hygini) pp. m., Wąsowicz: Ignini nr 9 i 19; (Włodarski 11 I Wrocław).

$11 \mathrm{~d}$ Świętego $\mathrm{Sab}<\mathrm{i}>$ nijego mę<czennika $>$ - Sabini m., Włodarski w tym dniu nie notuje; Wąsowicz: nr 19.

12 e Świętego Arkadyjego m<ęczennika> - Archadii m., Włodarski nie notuje tego świętego; Wąsowicz: nr 9 i 19.

13 f Świętego Ilaryjego bisku<pa> - Hilarii ep., Włodarski: Kraków, Lubusz, Płock, Włocławek, Wrocław; Wąsowicz: nr 2, 3, 7, 12, 16, 18.

Luty:

4 g Świętego Wedast<a> - Vedasti ep.; dzień tego świętego występuje w kalendarzach 6 II lub 7 II (zazwyczaj jako Amandi et Vedasti), ale nie 4 II, por. Włodarski, Wąsowicz.

7 c Świętej Apoloni<ji> - Apollonie v. m.; we wszystkich kalendarzach występuje 9 II.

8 d Świętego Emilija<na> - Emiliani (Aemiliani), było kilku świętych o tym imieniu, żaden nie występuje w kalendarzach średniowiecznych w Polsce, w kalendarzach obcych święto jego nie było nigdzie obchodzone 8 II.

9 e Świętego Amona - Ammoni m., Włodarski nie notuje tego świętego; Wąsowicz: 7 II bez powołania się na polski kalendarz, w kalendarzach obcych 19 III.

10 f Świętej Sotery - Sotheris v., Włodarski: Kraków, Wrocław; 11 II Kraków, Lubusz; Wąsowicz: nr 2, 3, 4, 6.

11 g Świętej Eufraz<yji> - Eufrosine v. (z Aleksandrii, V w.), Włodarski nie notuje tej świętej; Wąsowicz zna tylko św. Eufrozynę (Eufraksję) z Tebaidy, której święto obchodzone było 13 III. W wielu wykazach świętych znajdujemy jednak św. Eufrozynę z Aleksandrii, której kult wypadał 1 stycznia lub 11 lutego (por. np. Encyklopedia kościelna 1874: 98-99; Radoński 1947: 115; Encyklopedia katolicka 1989: 1289).

12 a Świętego Damija<na> - Damiani m., Włodarski: Włocławek (13 II Kraków); Wąsowicz nie notuje.

${ }^{3}$ W identyfikacji świętych odwołujemy się tu do wykazów świętych zamieszczonych w: Włodarski (red.) 1957: 134-217, 221-261 (skrót: Włodarski) oraz Wąsowicz 2013: 598-603 (Kalendarze świat polskich diecezji okresu przedtrydenckiego), 630-660 (Święta stałe kalendarzy) (skrót: Wąsowicz). W przypadku Włodarskiego podajemy diecezję, na którą on się powołuje, a cytując Wąsowicza, numer kalendarza, na którym oparł swój wykaz świąt. W pracy Wąsowicza występuje poważny błąd w Podstawie kalendarzy, bowiem zostało tam wymienionych 20 kalendarzy (Wąsowicz 2013: 598), jednak w dalszej części pracy liczba ich jest większa o dwa. Według informacji uzyskanej od Autora $\mathrm{nr} 21$ to Sakramentarz tyniecki, a nr 22 to Missale plenarium. Identyfikując świętych, posługiwaliśmy się też innymi licznymi publikacjami z tego zakresu. 
13 b Świętego Julijana - Juliani m., Włodarski: Lubusz; 15 II Włocławek; 17 II Wrocław; 19 II Kraków; Wąsowicz: nr 12.

14 c Świętego Witalis<a $>$ - Vitalis et soc. m., Włodarski: Kamień; Wąsowicz: nr 22.

15 d Świętego Fausty<na> - Faustini prb., Włodarski: Wrocław; Wąsowicz: Faustini et Iovitae m. nr 20.

16 e Świętego Feliks $<a>-$ Felicis, nigdzie nie jest notowany w tym dniu; Wąsowicz wymienia Felicis ep. w dniu 20 II w nr 9, 19.

18 g Świętego Sylwa $<$ na $>$ - Silvani (Silvi) m., nigdzie nie jest notowany w tym dniu; Wąsowicz wymienia go 17 II (bez podania źródła).

W kalendarzu występuje 17 imion, wśród nich pięć, których Stownik staropolskich nazw osobowych (dalej SSNO) nie notuje: Arkadyj, Emilijan, Iginij, Sotera, Wedast. Również słownikom nie jest znana forma january jako nazwa stycznia (zob. Borejszo 1989/1990: $23^{4}$ ).

Mamy przed sobą dziwny kalendarz, bo nie znajdziemy jego odpowiednika w znanych kalendarzach w Polsce i w innych krajach europejskich. Niemożliwe jest wskazanie diecezji lub jakiegoś środowiska, w którym mógłby być używany. Obok kilku świętych, których imiona umieszczone są prawidłowo we właściwym dniu ich kultu, znajdujemy imiona przypisane dniom nieznanym innym kalendarzom, np. św. Wedasta, św. Emilijana, św. Feliksa, św. Sylwana, albo rzadko w nich notowane, np. św. Arkadyjego, św. Ammona, św. Eufrazyji. W dodatku brakuje św. Doroty, czczonej powszechnie 5 lutego, a św. Apolonia umieszczona została 7 lutego, a nie 9 lutego, jak to jest we wszystkich kalendarzach z epoki. A zatem mamy tu do czynienia albo $\mathrm{z}$ jakimś kalendarzem, który był używany w nieznanym nam środowisku, albo ze zwykłą pomyłką kopisty. I to ostatnie przypuszczenie najlepiej thumaczy osobliwość tego fragmentu kalendarza. Potwierdza to również oznaczenie 4 i 5 lutego jako idy zamiast nony oraz 12 i 13 lutego jako kalendy zamiast idy oraz brak na samym początku skrótu KL (=Kalendae), na którego wpisanie pozostawiono wolne miejsce.

Kalendarz prawdopodobnie został źle rozplanowany i, korzystając z jakiegoś wzorca, pomylono w nim dni oraz rozmieszczenie świętych. Istnieje duże prawdopodobieństwo, że wpływ na to mogło mieć użycie dwóch kolorów atramentu. Rubrykowanie litery $S$ (świętego, świętej) wskazywałoby, że tekst pisany był wpierw czarnym atramentem, a potem czerwonym (ale mogło być odwrotnie), co spowodowałoby te omyłki. Być może błędy te szybko zauważono, kopiowania nie dokończono i pergamin został przeznaczony na makulaturę. Później zapewne podjęto prace nad nową, poprawną już wersją kalendarza.

Pergaminowa karta z fragmentem polskiego kalendarza, dzisiaj właściwie luźna, stanowiła wyklejkę tylnej okładki, o czym świadczą ślady kleju oraz odciski i przedziurawienia po pięciu niezachowanych guzach tylnej okładziny rękopisu. Karta posiada wymiary $29,2 \mathrm{~cm} \times 19,2 \mathrm{~cm}$, lecz trzeba ją obrócić poziomo, aby czytać zawarty na niej tekst a wtedy uzyskujemy urywek karty o odwrotnych wymiarach. Została wykrojona ze znacznie większego rękopisu i wtórnie wykorzystana do

\footnotetext{
${ }^{4}$ Autorka notuje tylko nazwy januar i januaryjus, obie z XVI wieku.
} 
oprawy. Z tego powodu utracone zostały urywki tekstu w miesiącu lutym, ponieważ odcięto końce wyrazów z imionami świętych.

Zachowany fragment świadczy, że rękopis kalendarza został bardzo starannie wykonany. Pisany jest czerwonym i czarnym atramentem. Czarnym kopista wyznaczył marginesy (górny około 3,5 cm, lewy około $5,5 \mathrm{~cm}$ ) oraz kolumny na wpisanie kolejnych dni miesiąca, liter oznaczających dni tygodnia i dni miesiąca według stylu rzymskiego, wreszcie poliniował pergamin co 0,9-1 cm. Razem poszczególne kolumny z wykazem świętych w styczniu zajmują szerokość 12,4 cm, a odległość do kolumny przeznaczonej na luty wynosi $1,7 \mathrm{~cm}$. Czerwonym atramentem pisarz wprowadził oznaczenia liczbowe, kalendy, nony, idy oraz dni świąteczne.

Tekst liczy 16 wersów. Jeśli w styczniu kończy się na 13 dniu, z dodaniem na początku informacji o tym miesiącu, a luty zawiera wykaz dni od 4 do 19, to pierwotnie karta, z której wycięto ten fragment (o wysokości 19,2 cm) musiała liczyć co najmniej $44 \mathrm{~cm}$, brakuje bowiem 18 dni stycznia, trzech wersów z opisem dotyczących lutego i pierwszych trzech dni lutego (razem około $24 \mathrm{~cm}+$ margines dolny). Kalendarz zatem posiadał wymiary dużego folio. Ocalały tylko urywki dwóch miesięcy. Patrząc na ich rozmieszczenie, należy przypuszczać, że całość kalendarza (wykaz świąt i świętych do grudnia) musiała zajmować przynajmniej pięć kart (albo miał formę zwoju długości około $120 \mathrm{~cm}$ ).

Cudem zachowany w rękopisie nr 1564 urywek polskiego kalendarza to albo kalendarz wieczny, albo partykularny. Jeżeli wieczny, to nie da się określić na który rok był przeznaczony, gdyż nie mamy w nim podanego dnia niedzielnego (littera dominicalis). Nie występuje też w tym fragmencie żadne ruchome święto, co uniemożliwia ustalenie roku, w którym miał być używany. Nie możemy jednak wykluczyć, iż gdzieś w innym, niezachowanym miejscu rękopisu, znajdowała się informacja o literze niedzielnej. Jeśli zaś przyjmiemy, że tą literą jest akurat wpisana 1 stycznia na czerwono litera A, bo w kalendarzach przeznaczanych na określony rok kolorem wyróżniano niedzielę (Wąsowicz 2013: 323, przypis 29), wtedy byłby to kalendarz na rok 1391 lub 1402 (Włodarski (red.) 1957: 356) (według autorów katalogu rękopisów średniowiecznych Biblioteki Jagiellońskiej rok 1390 lub 1396). Chyba tylko te lata można brać pod uwagę, zważywszy na czas powstania kodeksu nr 1564 i jego oprawy. Polski kalendarz z oczywistych powodów nie mógł być kalendarzem liturgicznym, zawiera najprostsze elementy, typowe dla tych, które spotykamy np. w livres d'heures. Według autorów wspomnianego katalogu jest to Kalendarium liturgicum ritus Palaeoslavici (Benedictinorum?), jednak takie przypuszczenie jest nieprawdopodobne. Nic też w tym fragmencie kalendarza nie wskazuje na jego związek z benedyktynami obrządku słowiańskiego, sprowadzonymi do Krakowa przez królową Jadwigę.

Kodeks został oprawiony zapewne krótko po 1404 roku, najpewniej w Krakowie ${ }^{5}$ i wtedy jako wyklejki użyto fragmentu kalendarza. Zachowany urywek spisany został jednak wcześniej - u schyłku XIV wieku lub w pierwszych latach XV stulecia. Potem

${ }^{5}$ Według A. Lewickiej-Kamińskiej (1977: 57, przypis 120) rękopis oprawiono na Śląsku, co nie wydaje się jednak prawdopodobne. Rękopis nr 1564 należał do Tomasza ze Strzempina (1398-1460), profesora i rektora Akademii Krakowskiej, biskupa krakowskiego. Może on oprawił rękopis i dzięki niemu trafił tam polski kalendarz? 
posłużył jako makulatura. Na stronie zawierającej tekst znajduje się bardzo dużo (w różnym położeniu) drobnych zapisek łacińskich, wyrazów i ich fragmentów, liter, często też powtarzanych - są to wyraźnie próby piór i nie zostaną one tutaj omówione, ponieważ nie wnoszą nic do wiedzy o kalendarzu. Odwrotna strona karty różni się od karty recto i nie posiada już tak wielu zapisek. Przytoczmy najdłuższą z nich: domine deus noster quam admirabile.

Dla jakich celów powstał publikowany tu kalendarz i do kogo był adresowany? Odpowiedź wydaje się prosta. O świętach, postach i różnych zarządzeniach kościelnych informował wiernych podczas mszy duchowny, ale jak pisze Izabela Skierska:

Niekiedy docierano do wiernych z informacjami poprzez plakatowanie zarządzeń biskupa, przybijając karty pergaminowe ze stosownymi tekstami na drzwiach lub we wnętrzach świątyń katedralnych, kolegiackich, ale i parafialnych. Nie są mi znane takie obwieszczenia o zasadach weneracji świąt czy np. wykazy czynności dozwolonych lub zabronionych w święto. Wiadomo jednak, że wywieszano pergaminowe karty ze spisem świąt. Tak miał czynić (w chórze lub zakrystii kościoła katedralnego) dziekan kapituły płockiej lub jego zastępca - zgodnie ze zwyczajem innych kościołów, jak czytamy w statutach biskupa Jakuba Kurdwanowskiego. Wywieszenie w chórze (prezbiterium) takiej karty - przeznaczonej przede wszystkim do użytku duchownych - dawało szansę choćby części wiernych na »zerknięcie« do wykazu. Znane są procedury publikacji na dużych, jednostronnie zapisanych pergaminowych kartach postanowień synodów diecezjalnych i prowincjalnych, a w uchwałach tych przecież, przypomnijmy, odnoszono się do weneracji świąt obowiązkowych czy wręcz podawano katalog takich świąt. Wedle J. Sawickiego, owe plakaty skierowane były do kleru. Najpewniej oczywiście przede wszystkim do niego, ale jeśli karty były eksponowane w kościele czy na jego wrotach, trzeba przypuszczać, że mogła się z nim zapoznać część wiernych świeckich - przynajmniej ta, która umiała czytać (Skierska 2008: 211-212, zob. też Skierska 2003: 40-42).

Niewątpliwie fragment kalendarza z kodeksu nr 1564 jest tego typu zabytkiem, pergaminowym obszernym ,plakatem”, przypominającym formą zwój, który informował parafian o przypadających w ciągu roku uroczystościach i świętach. Wyjątkowość jego polega na wymienionych w nim imionach świętych i to, że sporządzony został w języku polskim.

W tytule niniejszego artykułu chcieliśmy umieścić słowa „najdawniejszy kalendarz polski", jednak starszy od niego, bo datowany na lata 1360-1370, był kalendarz odnaleziony przez Jerzego Zatheya, który podczas ostatniej wojny pracował jako kustosz w Dziale Rękopisów Biblioteki Narodowej i tak m.in. o nim pisał:

W jednym z katalogowanych przeze mnie rękopisów, pochodzących z biblioteki Wikariuszy przy Kollegiacie Panny Marii w Wiślicy, - tytułu, ani sygnatury w tej chwili nie pamiętam, - na kilkunastu dość szerokich paskach pergaminowych chroniących papier przy niciach zszywających składki zauważyłem słowa polskie. Bliższe zbadanie ich - bez rozszywania rękopisu - pozwoliło mi ustalić, że był to fragment kalendarza w języku polskim, pisanego dużymi, szerokimi, gotyckimi literami psałterzy, pismem wieku XIV. Nierozszytych fragmentów nie mogłem sfotografować, z wykonaniem tego czekałem niestety na „lepsze czasy”. [...] Dr J. Karwasińska, której pismo to pokazywałem, zgadzała się z oznaczeniem czasu napisania tych fragmentów na lata 1360-1370. Datą świadcząca o terminie, przed którym kalendarz został pocięty i użyty przy oprawieniu rękopisu, był r. 1430 (lub 1430 któryś) wymieniony w treści, jakieś zapiski na karcie naklejonej na drzewo oprawy. Zapiska ta, jak wynikało z jej formy i treści, powstała, gdy rękopis był już oprawiony (Zathey 1949: 74). 
Niestety odnalezione paski uległy zatraceniu, a z zapisanych na nich imion Zathey po wojnie zapamiętał tylko około 20, wśród nich, co jest niezwykłe, Gorazda, świętego prawosławnego, ucznia św. Metodego. Wielce prawdopodobne, że kalendarz ten miał również formę zwoju, lecz jako już nieaktualny został pocięty i wykorzystany podczas oprawiania kodeksu.

Znamy zatem dwa rękopiśmienne kalendarze średniowieczne w języku polskim. Zachowany fragment z kodeksu nr 1564 jest zabytkiem bezcennym, świadczy, że w średniowiecznej Polsce były sporządzane kalendarze in lingua vulgaris, ale dotrwały do naszych czasów tylko ich szczątki. Poszerza to znacznie naszą wiedzę o funkcjonowaniu polszczyzny w piśmiennictwie tamtych czasów.

Pod względem językowym tekst kalendarza nie odbiega od grafii polskich zabytków z przełomu XIV i XV wieku, a sposób oddawania poszczególnych głosek potwierdza datowanie zapisu.

Samogłoska nosowa przednia zapisywana jest w nim przez $\varnothing, n p$. w wyrazie Swøtego oraz w początkowym fragmencie wyrazu mø<czennika $>$. Samogłoski nosowej tylnej w zachowanym fragmencie nie użyto.

Miękkość spółgłosek przed samogłoską zaznaczana jest nieregularnie, jednak w tych miejscach, w których pisarz ją wprowadził uczynił to za pomocą $y$, np. obrzazanye, vygylya, dnya. W innych miejscach opuszcza oznaczanie miękkości, np. dzen, Swøtego.

\section{S z e r e g $S-\breve{S}-\dot{S}$}

Głoska $s$ zapisywana jest przez $s$, np. Sabnyego, byskv<pa>, Wedast $<a>$, Sotery. Głoska $z$ oznaczana jest na dwa sposoby: przez $z$, np. obrzazanye, oraz przez $s z$, np. yeszu. Z uwagi na obcięcie karty niejednoznaczny interpretacyjnie pozostaje zapis Ewfras $<$.. >, ponieważ nie wiadomo czy pisarz oddał w nim głoskę $z$ przez $s$ czy też przez $s z$. Głoska š oznaczana jest zarówno przez $s z$, np. szestnaczcze, jak i przez $s$, np. Sczodry. Na oznaczenie głoski ś pisarz używa regularnie $s, \mathrm{np}$. w wyrazach trydzesczy, osm, Swøtego.

\section{Inne głos ki}

Głoska $i$ zapisywana jest przez $y$, np. dny, Damya<na>, oraz przez $i$, np. Emilya $<n a>$, Vytalis $<a>$. Głoskę y pisarz oznacza przez $y$, np. Janvary, Sczodry. Głoska $e$ oddawana jest zawsze przez e, np. szestnaczcze, sczodrego, obrzazanye. Głoska $o$ zapisywana jest przez $o$, np. nocz, godzyn, osm. Głoskę $u$ pisarz oznacza najczęściej przez $v$, np. Janvary, Lvcyana, byskv<pa>, ale również przez $u$, np. yeszu. Głoskę i pisarz zapisuje na trzy sposoby: przez $i$, np. ianvary, Ivlyana przez $g$, np. gyma, geden oraz przez y, np. yeszu, Swøtey. W pojedynczych zapisach litera y oznacza zarówno zgłoskotwórcze $i$, jak też $i$ niezgłoskotwórcze, np. vygylya, Igynyego, Ivlyana.

Głoska $p$ oddawana jest zawsze przez $p$, np. pap<ieża $>$, Apolony. Głoska $b$ zapisywana jest przez $b$, np. obrzazanye, byskv<pa>. Głoskę $m$ pisarz oznacza przez $m$, np. gyma, osm, Amona. Głoskę $f$ zapisano przez $f$, np. Ewfras $<y j i>$, Favsti<ny>, Fely$k s a$. Głoska $v$ oznaczana jest na dwa sposoby: przez $v$, np. vygylya, Vytalis $\langle a>$, oraz przez $w$, np. Swøtego, Wedast $<a>$. Głoska $t$ zapisywana jest zawsze przez $t$, np. try- 
dzesczy, szestnaczcze, Swøtego. Zaskakująca jest regularność tych zapisów, ponieważ w tamtym okresie bardzo często zapisywano tę głoskę zgodnie ze wzorcem łacińskim za pomocą połączenia liter $t$.

Głoskę $d$ pisarz oznaczał przez $d$, np. dny, geden, sczodrego. Głoska $c$ jest oznaczana na dwa sposoby: za pomocą $c$, np. Lvcyana, oraz za pomocą $c z$, np. nocz. Głoska 3 zapisana jest cztery razy, zawsze w ten sam sposób przez $d z$, np. trydzesczy, godzyn, dzen. Głoskę $n$ pisarz oznacza za pomocą n, np. Ianvary, dny, nocz, Amona. Głoska č zapisywana jest przez $c z$, np. sczodry. Głoskę $r$ pisarz zapisuje za pomocą litery $r$, np. Ianvary, sczodrego, Ewfras $<y j i>$. Głoskę ř pisarz zapisał przez $r z$ w wyrazie obrzazanye, jednak w wyrazie trydzieści przez $r$, co nie dziwi z uwagi na czas zapisu, ponieważ w ówczesnych polskich zabytkach językowych odnajdujemy tego typu oznaczenia w wielu zabytkach, np. w Kazaniach gnieźnieńskich zapisy: prykry (czyt. przykry) k. 175v, na kryszu (czyt. na krzyżu) k. 177v. Głoska l zapisywana jest zawsze przez l, np. vygylya, Lvcyana, Ilaryego. Głoskę ć pisarz zapisał przez cz w wyrazie szestaczcze. Głoska 3 została oznaczona przez $d z$, np. trydzesczy, godzyn, dzen. Głosę ń zapisano tylko w wyrazie dzen i oddano ją za pomocą $n$. Głoska $k$ została oddana dwa razy za pomocą $k$ w wyrazach byskv<pa> oraz Felyks $<a>$. Wyraz Archadyego trudno jest jednoznacznie zinterpretować, ponieważ nie poświadczono w literaturze dawnej imienia Archadyj. Za postacią, w której dwuznak ch należy interpretować jako głoskę $\chi$ a nie $k$ mogą przemawiać zarówno średniowieczne imię Archambołt (SSNO: I, 62), którego warianty fonetyczne zapisywano również przez $k$ (Arkambołt, Arkembołt, Jarkombołt), jak i Sstp, w którym pod hasłem Arka poświadczona jest jedynie postać Archa. W zachowanym fragmencie kalendarza nie ma drugiego zapisu głoski $\chi$, przez co nie sposób jednoznacznie wnioskować. Głoska $g$ zapisywana jest przez g, np. godzyn, Swøtego, Ilaryego.

Jak już podkreślaliśmy wcześniej, imiona: Arkadyj, Emilijan, Iginij, Sotera, Wedast nie zostały odnotowane przez SSNO. Nowe znalezisko uzupełnia listę średniowiecznych imion świętych i błogosławionych, które funkcjonowały w polskim Kościele. Wśród niewielkiego zbioru słownictwa zachowanego w kalendarzu wymieniliśmy dotąd jedynie nienotowaną nazwę stycznia january, ale warto również zwrócić uwagę na inne wyrazy, np. rzeczownik obrzazanie, którego obie postaci fonetyczne obrzezanie oraz obrzazanie notuje Sstp (Sstp: V, 384). Wśród poświadczonych tam form nie ma jednak mianownika liczby pojedynczej obrzazanie. Mianownik kolejnego rzeczownika wijilija, oznaczającego 'ostatni dzień przed świętem', poświadczony jest z zabytku pochodzącego z końca XV wieku, zatem odnaleziony zapis stanie się najstarszym poświadczeniem (Sstp: X, 221). Podobnie się stanie z dopełniaczem liczby pojedynczej szczodrego, który notowany jest w Sstp z Biblii królowej Zofii (Sstp: VIII, 543).

Fragment kalendarza w języku polskim pochodzący z Biblioteki Jagiellońskiej w Krakowie jest zatem nie tylko wyjątkowym znaleziskiem z uwagi na unikatowy charakter i niespotykane dotąd przeznaczenie, opisane jedynie w literaturze przedmiotu, ale również na zawartą w nim treść, która przez pomyłkę pisarza została najprawdopodobniej zmieniona. Dzięki temu zbiegowi okoliczności pergaminowa karta nie uległa zniszczeniu z powodu zużycia, ale została wykorzystana do wzmocnienia innego rękopisu, przez co ocalała. Dalsze badania i poszukiwania być może potwierdzą 
postawioną w artykule tezę o charakterze i losach średniowiecznego kalendarza, a z pewnością przyczynią się do upowszechnienia wiedzy o tym zabytku.

\title{
Bibliografia
}

Borejszo M., 1989/1990, Staropolskie nazwy miesięcy, „Slavia Occidentalis” 46/47, s. 19-32.

Włodarski B. (red.), 1957, Chronologia polska, Warszawa.

Encyklopedia katolicka, 1989, t. IV, red. R. Łukaszyk, L. Bieńkowski, F. Gryglewicz, Lublin. Encyklopedia kościelna podtug teologicznej encyklopedji Wetzera i Weltego z licznemi jej dopetnieniami, 1874, wyd. Michał Nowodworski, t. V, Warszawa.

Grotefend H., 1891-1898, Zeitrechnung des deutschen Mittelalters und der Neuzeit, t. 1-2, Hannover, HTML-Version, Ruth Horst: http://bilder.manuscripta-mediaevalia.de/gaeste/ grotefend/grotefend.htm.

Katalog łacińskich rękopisów średniowiecznych Biblioteki Jagiellońskiej. Tom XI. Sygnatury 1501-1575, 2016, oprac. A. Kozłowska, L. Nowak, A. Sobańska, W. Świeboda, R. Tatarzyński, W. Zega, Kraków.

Lewicka-Kamińska A., 1977, Z dziejów średniowiecznej oprawy książkowej na Śląsku, „Roczniki Biblioteczne" XXI, s. 27-90.

Radoński K., 1947, Święci i błogosławieni kościoła katolickiego. Encyklopedia hagiograficzna, Warszawa-Poznań-Lublin.

Skierska I., 2003, Obowiązek mszalny w średniowiecznej Polsce, Warszawa.

Skierska I., 2008, Sabbatha sanctifices. Dzień święty w średniowiecznej Polsce, Warszawa.

Sstp - Stownik staropolski, red. S. Urbańczyk, t. 1-11, Warszawa-Kraków 1953-2002.

SSNO - Stownik staropolskich nazw osobowych, red. W. Taszycki, t. 1-7, Wrocław 1965-1987.

Wąsowicz H., 2013, Chronologia średniowieczna, Lublin.

Zathey J., 1949, O kilku przepadtych zabytkach rękopiśmiennych Biblioteki Narodowej w Warszawie, w: Studia z dziejów kultury polskiej, red. H. Barycz i J. Hulewicz, Warszawa, s. 73-96.

\section{MARIUSZ LEŃCZUK, WIESŁAW WYDRA}

\section{A fragment of a Polish calendar from the $14^{\text {th }} / 15^{\text {th }}$ century from the Jagiellonian Library in Krakow}

\begin{abstract}
A manuscript stored in the Jagiellonian Library (no. 1564 from 1404) holds a fragment of a Polish calendar, previously unpublished, from the late $14^{\text {th }}$ century or the early $15^{\text {th }}$ century. Written on the last, extra parchment page, it is a fragment of a much larger manuscript. The first 13 days of January have survived ( 1 to 13 January) and 13 days of February ( 4 to 19 February). The fragment contains 17 names, five of which are not included in the Słownik staropolskich nazw osobowych (Dictionary of Old Polish Proper Nouns, W. Taszycki, ed., vol. 1-7, Wrocław 1965-1987), namely Arkadyj, Emilijan, Iginij, Sotera, Wedast. The word january (January, in Polish styczeń) has not been recognised by dictionaries, either. There is no equivalent of the calendar in question in Poland or other European countries. It is impossible to indicate the diocese or a milieu where it could have been used. The document includes a few names of saints properly attributed to the days of their cult and names
\end{abstract}


attributed to days not used in other known calendars. This leads to a conclusion that the calendar was either used in an unknown milieu or we are dealing with a simple error of the copyist. The latter theory best explains the peculiarity of this fragment of the calendar. This is confirmed by marking 4 nd 5 February as Ide rather than Nones, and 12 and 13 February as calends rather than Ides.

The calendar was probably erroneously planned by the copyist who confused the days and affiliation of saints. Perhaps these errors were spotted early, the copying process was never completed and the parchment was recycled.

Most probably, the intention behind the calendar (1564) was a large parchment "poster", reminiscent of a scroll, used to inform the congregation about the holidays in the year. The calendar is unique because of the names of saints included in it and the fact that it is written in Polish.

Keywords: medieval manuscript, fragment of a Polish calendar, wrong calendar template. 